\title{
Activation of human neutrophils by dotriacontane from Tynanthus micranthus Corr. Méllo (Bignoniaceae) for the production of superoxide anions
}

\author{
Leticia Gomes Carneiro'; Francis José Zortéa Merino"; Samanta Daliana Golin \\ Pacheco"'; Fernanda Colombi Cansian'v; Letícia Freire de Oliveirav'; Josiane de \\ Fátima Gaspari Dias ${ }^{\mathrm{VI}}$; Paulo Roberto WunderVII; Vinícius Bednarczuk OliveiravIII \\ Andersson Barison'x; Deise Prehs Montrucchiox; João Cleverson Gasparettoxl; \\ Obdulio Gomes Miguel ${ }^{\mathrm{XII}}$; Marilis Dallarmi Miguel ${ }^{\mathrm{XIII}}$
}

\begin{abstract}
RESUMO
A espécie Tynanthus micranthus Corr. Méllo, popularmente conhecida como "Cipó Cravo" ou "Craveiro", é usualmente utilizada como estimulante e afrodisíaca, e encontrada no norte do Estado do Paraná - Brasil. Os objetivos desse estudo foi isolar o alcano dotriacontane de $T$. micranthus e verificar a ativação de neutrófilos humanos para a produção de ânios superóxidos pelo método de redução do nitroblue tetrazolium (NBT), comparando com a ativação obtida pelo dotriacontane comercial. O extrato etanólico de folhas secas de T. micranthus foi preparado por meio de aparelho Soxhlet modificado. Em seguida o extrato etanólico foi fracionado com $n$ hexano para a obtenção da fração hexano a qual foi submetida a coluna cromatográfica para obtenção do composto dotriacontane. A substância foi identificada por espectroscopia de RMN de ${ }^{1} \mathrm{H}$ e ${ }^{13} \mathrm{C}$. O dotriacontane isolado e comercial foram avaliados pelo ensaio do NBT para verificação da ativação de neutrófilos humanos. O dotriaconte isolado e o comercial ativaram os neutrófilos $(10,0 \mu \mathrm{g} / \mathrm{mL})$ quando comparados com o controle positivo de ativação phorbol myristate acetate (PMA) $(10,0 \mu \mathrm{g} / \mathrm{mL})$. No teste quantitativo o dotriacontane comercial demonstrou significativa ação quando comparado com o PMA $(10,0 \mu \mathrm{g} / \mathrm{mL})$. A substância dotriacontane, identificada pela primeira vez no gênero Tynanthus. obteve resultados positivos na ativação dos neutrófilos humanos para a produção dos ânions superóxidos.
\end{abstract}

Palavras-chave: Tynanthus micranthus; Bignoniaceae; Dotriacontane; Ativação de neutrófilo

\footnotetext{
Post-Graduation in Pharmaceutical Sciences Program, Paraná Federal University, Curitiba, PR, Brazil. eticiac_10@hotmail.com

Dr in Pharmaceutical Sciences, Paraná Federal University, Curitiba, PR, Brazil. secocio@yahoo.com.br

I'I Dra in Pharmaceutical Sciences, Paraná Federal University, Curitiba, PR, Brazil. samdagol@gmail.com

IV Dra in Pharmaceutical Sciences, Paraná Federal University, Curitiba, PR, Brazil. fecolombi@hotmail.com

$\checkmark$ Post-Graduation in Pharmaceutical Sciences Program, Paraná Federal University, Curitiba, PR, Brazil. lela-freire@hotmail.com

vi Dra in Pharmaceutical Sciences, Paraná Federal University, Curitiba, PR, Brazil. jodias@ufpr.br

VII Dr, Paraná Federal University, Curitiba, PR, Brazil. prwgolfista@gmail.com

VIII Dr, Paraná Federal University, Curitiba, PR, Brazil. vinicius.bednarczuk@hotmail.com

Ix Dr, Paraná Federal University, Curitiba, PR, Brazil. anderbarison@gmail.com

x Dra, Paraná Federal University, Curitiba, PR, Brazil. dpmontrucchio@ufpr.br

x। Dr, Paraná Federal University, Curitiba, PR, Brazil. joaogasparetto@uol.com.br

XII Dr, Paraná Federal University, Curitiba, PR, Brazil. obdulio@ufpr.br

XIII Dra, Paraná Federal University, Curitiba, PR, Brazil. dallarmi@ufpr.br
} 


\begin{abstract}
The species Tynanthus micranthus Corr. Méllo, is popularly known as "Cipó Cravo" or "Craveiro", and is usually used as a stimulant and aphrodisiac, and found in the north of the State of Paraná - Brazil. The isolate the alkane dotriacontane from T. micranthus and to verify its action on the activation of human neutrophils to produce superoxide anions by the nitroblue tetrazolium reduction method (NBT), in comparison with the activation obtained by commercial dotriacontane. The ethanolic extract dried leaves was prepared by modified Soxhlet apparatus. Then the ethanolic extract was fractionated with $n$-hexane to obtain the hexane fraction which was submitted to the chromatographic column to obtain the compound dotriacontane. The substance was identified by ${ }^{1} \mathrm{H}$ and ${ }^{13} \mathrm{C}$ NMR spectroscopy. Isolated and commercial dotriacontane were evaluated by the NBT assay for verification of the activation of human neutrophils. The isolated and commercial dotriacontane activated neutrophils $(10.0 \mu \mathrm{g} / \mathrm{mL})$ when compared to phorbol myristate acetate (PMA) $(10.0 \mu \mathrm{g} / \mathrm{mL})$. In the quantitative test commercial dotriacontane induced significant activation when compared to PMA $(10.0 \mu \mathrm{g} / \mathrm{mL})$. The substance dotriacontane, first time identified in the genus Tynanthus. The dotriacontane was shown to be important to confirm the activation of human neutrophils to produce superoxide anions.
\end{abstract}

Keywords: Tynanthus micranthus; Bignoniaceae; Dotriacontane; Neutrophhil Activation

\title{
1. INTRODUCTION
}

Neutrophils are the most abundant leukocytes in peripheral blood, and play an important role in acute inflammatory processes. They have a multi-lobed nucleus and several cytoplasmic granules, which are able to digest different types of antigens such as toxins and pathogens through the mechanism of phagocytosis (Zychlinsky et al., 2003). During phagocytosis, the stages of degranulation and digestion occur and they are related to the release of proteolytic enzymes and reactive oxygen species (ROS) (Johansson et al., 2002). In the process of digestion of the microorganisms, neutrophils use two different mechanisms, the non-oxidative and oxidative mechanisms, both essential in the microbicidal action. The first mechanism mentioned is the action of lysozyme, lactoferrin and cationic proteins at a very low pH inside the vacuole (Verhoef, 1992).

The oxidative mechanism occurs after intense metabolic activity associated to an increase in oxygen consumption and glucose metabolism, which happens after antigen phagocytosis. Glucose is used to form $\mathrm{CO}_{2}$ and pentose in the glucosemonophosphate pathway, in which, during its activation, NADPH is formed. Thereby, 
there is a generation of hydrogen peroxide and superoxide anions, formed by the reduction of oxygen, in addition to simple forms of oxygen and hydroxyl radicals. Superoxide anions are formed by the reduction of $\mathrm{O}_{2}$ from the reduced NADPH cofactor; the simple forms of oxygen are formed by a reaction mediated by the enzyme myeloperoxidase (MPO), from the chloride ion and hydrogen peroxide; and the hydroxyl radicals come from a reaction between superoxide ions and hydrogen peroxide (Verhoef, 1992).

Natural products can be used to activate defense mechanisms, as well as stimulate the immune response, some acts in humoral cell-mediated immunity (BinHafeez et al., 2001; Ghule et al., 2006) and others activates the cellular components in the immune system (Ghule and Yeole, 2012). Some medicinal plants have demonstrated immunomodulatory effects as Panax ginseng (Kang and Min, 2012), Withania somnifera (Davis and Kuttan, 2000), Uncaria tomentosa (Akesson et al., 2003), and they belongs to different botanical families.

Numerous secondary metabolites of various medicinal plants are known for theirpotent immunomodulatory effects (Sharma et al., 1996; Costa-Silva et al., 2015). The main constituent of clove oil is a terpene eugenol with the ability to regulate the LOX-5 enzyme induced by neutrophils, acting on the inhibition of leukotrienes LTB4, LTC4 and LTD4. The flavonoid quercetin present in several families of the plant kingdom has the capacity to inhibit neutrophil degranulation and the production of superoxide anions (Corrêa et al., 2008).

Species of the genus Tynanthus are used in folk medicine for various conditions. The species T. fasciculatus is used for dyspepsia, carminative, antidiarrheal and intestinal worms, besides being stimulant and aphrodisiac (Lopes et al., 2008). T. panurensis is used as analgesic, for diabetes and rheumatism, as tonic, energizing and aphrodisiac (Plaza et al., 2005). T. elegans as carminative and aphrodisiac (Correa, 1974). T. guatemalensis used in the treatment of diabetes (Ferrier, 2013) e $T$. schumannianus for diarrhea (Muñoz et al., 2000).

T. micranthus, popularly known as "Cipó Cravo" or "Craveiro", is found mainly in the State of Paraná - Brazil and is used in folk medicine to aphrodisiac purposes 
(Cansian et al., 2014) and, in the form of tea for healing (Custódio et al., 2010). Previous works on the specimen reports apigenin and $\beta$-sitosterol as well as biological activities to fractions and extracts (Cansian et al., 2012), including allelopathic (Cansian et al., 2013), antioxidant and tyrosinase activation (Cansian et al., 2014). Other chemical groups such as flavonoids (dihidroflavonoids and leucoanthocyanidins), steroids and/or triterpenoids and heterosidic anthraquinones were detected in this species (Cansian et al., 2012), as like as the eugenol, which is present in the essential oil (Custódio et al., 2010).

In this perspective, this work aimed at the isolation of the dotriacontane of T. micranthus species and the evaluation of the ability of dotriacontane to activate human neutrophils to produce superoxide anions. In addition, the activity of the dotriacontane isolate was compared to the activity of the commercial dotriacontane Sigma-Aldrich ${ }^{\circledR}$.

\section{MATERIALS AND METHODS}

\subsection{Botanical Material}

Leaves of $T$. micranthus were collected in the city of Quinta do Sol, Paraná,

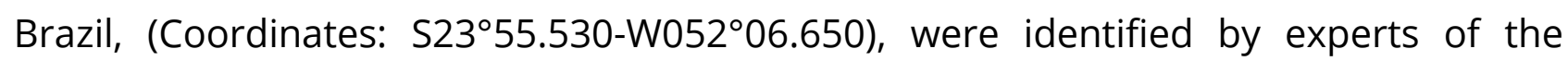
Botanical Museum of Curitiba and a voucher specimen was deposited under number 231.071. The project was regularized in Brazil in accordance with the resolution $n^{\circ} .35$, in April 27 $7^{\text {th }}$ of 2011 the Brazilian Ministry of Environment which provides for regulating access to genetic heritage activities.

\subsection{Extraction and Isolation}

Dried and powdered leaves (987 g) were extracted with ethanol for eight hours on a Soxhlet apparatus modified under the registration PI 0601703-7(Carvalho et al., 2009). After solvent removal to $120 \mathrm{~mL}$ under reduced pressure, the crude ethanol extract (CEE) was subjected to liquid-liquid extraction with $n$-hexane solvent, resulting in $\mathrm{n}$-hexane fraction $(7.12 \mathrm{~g})$. The $\mathrm{n}$-hexane fraction $(10.65 \mathrm{~g})$ was submitted 
to a silica gel 60 column chromatography eluted with an increasing gradient system of solvents concentration, being AcOEt in n-hexane (from 0 to $100 \%$ ) yielding 135 subfractions of approximately $20 \mathrm{~mL}$. Sub-fractions 1-8 were pooled according to TLC analysis and further purified on silica gel GF254 $(20 \times 5 \mathrm{~cm})$ chromatographic plates, eluted with toluene and AcOEt $(93: 7, v / v)$. The spots were visualized by revelation with vanillin phosphoric component sprayed on a small part of plate edge. The compounds were extracted from chromatographic plates and, the solvent was removed under reduced pressure to give dotriacontane as a white powder.

\subsection{General procedures and chemicals}

All NMR experiments were acquired at $303 \mathrm{~K}$ in $\mathrm{CDCl}_{3}$ on a Bruker DPX 200 NMR spectrometer operating at $4.7 \mathrm{~T}$, observing ${ }^{1} \mathrm{H}$ and ${ }^{13} \mathrm{C} 200.13$ and $50.32 \mathrm{MHz}$ respectively. The instrument was equipped with a 5-mm quadrinuclear direct detection probe. The ${ }^{1} \mathrm{H}$ and ${ }^{13} \mathrm{C}$ NMR chemical shifts are given in ppm related to TMS signal at $0.00 \mathrm{ppm}$ as internal reference.

\subsection{NBT assay}

The assay was approved by Ethics Committee, from Paraná Federal University (UFPR), under registration number CEP/SD: 1033.158.10.11, CAAE: 0090.0.091.000-10.

\subsubsection{Reagents preparation}

PBS 1 was prepared according to Dulbecco and Vogt (1954) by dissolving in $1000 \mathrm{~mL}$ distilled water: $8 \mathrm{~g} \mathrm{NaCl}, 0,2 \mathrm{~g} \mathrm{KCl}, 1.15 \mathrm{~g} \mathrm{Na} 2 \mathrm{HPO}_{4}$ and 0,2 $\mathrm{g} \mathrm{KH} \mathrm{PO}_{4}$. PBS 2 was prepared by dissolving in $250 \mathrm{~mL}$ of distilled water: $8 \mathrm{~g} \mathrm{NaCl}, 0.2 \mathrm{~g} \mathrm{KCl}, 1.15 \mathrm{~g}$ $\mathrm{Na}_{2} \mathrm{HPO}_{4}$ and $0.2 \mathrm{~g} \mathrm{KH}_{2} \mathrm{PO}_{4}$. After preparation the solutions were stored under refrigeration.

The PMA was prepared by weighing $1 \mathrm{mg}$ of PMA and dissolving in $1 \mathrm{~mL}$ of DMSO. From the first solution it was diluted to $100 \mu \mathrm{g} \cdot \mathrm{mL}^{-1}$ in distilled water and from the second solution it was diluted to $10 \mu \mathrm{g} \cdot \mathrm{mL}^{-1}$ in distilled water. After preparation the solutions were stored under freezing. 


\subsubsection{Neutrophils isolation}

For the separation of neutrophils from human peripheral blood, a methodology adapted from the studies of Markert et al. (1984), Wunder et al. (1993), Balla et al. (1993) and Balla et al. (1996) whose principle is based on cell separation by density gradient centrifugation using a mixture of high density hydrophilic neutral polysaccharides. The blood $(3 \mathrm{~mL})$ was filled with distilled water $(36 \mathrm{~mL})$ in falcon tube and homogenized for 30 seconds for hemolysis of erythrocytes. After addition of PBS $2(12 \mathrm{~mL})$ the tube was centrifuged for 10 minutes at $2000 \mathrm{rpm}$ and the supernatant discarded. Cells were resuspended with PBS $1(3 \mathrm{~mL})$ and the resulting suspension placed on Histopaque ${ }^{\circledR}-1077$. After centrifuging for 25 minutes at $1500 \mathrm{rpm}$ the supernatant discarded and the cells resuspended with $3 \mathrm{~mL}$ of PBS 1. For a further 10 minutes the solution was centrifuged at $2000 \mathrm{rpm}$, removing the supernatant and resuspending the pellet gently in $200 \mu \mathrm{L}$ of PBS 1. The last suspension was called neutrophil suspension and was used in the assays.

\subsubsection{Qualitative NBT assay}

For this assay, adapted and modified methodology was used by Park et al. (1968), Park and Good (1970), Levinsky et al. (1983) and Glasser and Fiederlein (1990). The principle of this test is based on using the NBT dye to verify the presence of reactive oxygen species because the NBT is reduced, forming a blue metabolite in the cytoplasm of the cells, called formazan.

Circles were drawn with approximately $1 \mathrm{~cm}$ in diameter onto glass slides, and $10.0 \mu \mathrm{g} / \mathrm{mL}$ PMA was added, in each of them, which served as a positive control of cell activation, and other remaining circles, the isolated dotriacontane (ID) and the commercial dotriacontane (CD) in concentrations of $10.0 \mu \mathrm{g} / \mathrm{mL}$. The glass slides were left drying at room temperature for 48 hours. Two circles were reserved for the negative control, the first having only the neutrophil suspension without the presence of NBT, with the aim to verify the viability of neutrophils, and the second one containing the neutrophil suspension and addition of NBT to confirm the nonactivation of neutrophils by NBT. A neutrophil cell suspension in phosphate buffered 
saline (PBS 1) was added $(50 \mu \mathrm{L})$ in a plate containing the ID and CD samples in addition to the PMA and NBT controls, previously dried, and incubated in moist chamber ( $37^{\circ} \mathrm{C}, 20 \mathrm{~min}$.). Further, they were washed with PBS 1 (10x) and then NBT (4 $\mathrm{mM}$ ) was added (2 drops), incubating it for 15 minutes. After this period, the plate were washed $(5 \mathrm{x})$ with PBS 1, dried and stained with safranin solution $0.25 \%$ for 10 minutes. Finally, after the removal (washed $3 \times$ with distilled water) of the dye (room temperature), the glass slides were examined under a optical microscope (immersion oil) or observation of blue cells. The test was performed three times.

\subsubsection{Quantitative NBT assay}

The assay was conducted according to Sharma et al. (2012) with modifications. For the test a 96-well plates was used and $50 \mu \mathrm{L}$ of $10.0 \mu \mathrm{g} / \mathrm{mL}$ PMA was placed in another well plate, $50 \mu \mathrm{L}$ of $\mathrm{CD}$ at $10.0 \mu \mathrm{g} \mathrm{mL}$, 48 hours before the test. Subsequently in the wells were added $50 \mu \mathrm{L}$ of the cell suspension incubated at $36.8^{\circ} \mathrm{C}$ in a humid chamber for 20 minutes. After incubation, the wells were washed gently with PBS 1 (4x). The NBT was added $(50 \mu \mathrm{L})$ in the wells with the sample and in another well for NBT control and incubated for 15 minutes at $37^{\circ} \mathrm{C}$. The wells were washed $3 x$ with PBS 1 and then $100 \mu \mathrm{L}$ of DMSO and $100 \mu \mathrm{L} 2 \mathrm{M}$ potassium hydroxide solution added. The plate was gently shaken for 15 minutes and the reading performed on a microplate reader at $650 \mathrm{~nm}$. The result was expressed as the average absorbance obtained for the NBT control, and the NBT $(X)$ was obtained with the sum of NBT plus s / NBT divided by 2 . The test was made in triplicates and the results submitted to Tukey's test $(p<0.05)$ with the aid of the Sisvar ${ }^{\circledR}$ program (Ferreira, 2011).

\section{RESULTS}

\subsection{Phytochemical investigation}

The phytochemical investigation of Tynanthus micranthus resulted in the isolation of dotriacontane $(4.9 \mathrm{mg})$ from the $\mathrm{n}$-hexane fraction, containing a linear $\mathrm{C}_{32}$ 
long chain hydrocarbon (Figure 1). The isolated substance was compared to SigmaAldrich ${ }^{\circledR}$ standard by NMR spectroscopy.

${ }^{13} \mathrm{C} \mathrm{NMR}\left(\mathrm{CDCl}_{3} ; 50 \mathrm{MHz}\right): 31.9\left(\mathrm{CH}_{2}\right), 29.7\left(\mathrm{CH}_{2}\right), 22.7\left(\mathrm{CH}_{2}\right), 14.1\left(\mathrm{CH}_{3}, \mathrm{C}-1 ; \mathrm{C}-\right.$ 32); ${ }^{1} \mathrm{H}$ NMR $\left(\mathrm{CDCl}_{3} ; 200 \mathrm{MHz}\right) 0.88(6 \mathrm{H}, t) ; 1.25(60 \mathrm{H}, \mathrm{s})$.

Figure 1 - Dotriacontane structure

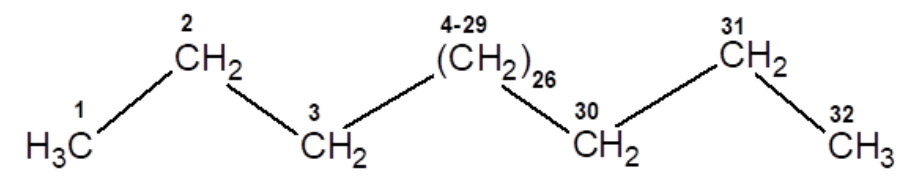

\subsection{Qualitative NBT assay}

The influence of dotriacontane from $T$. micranthus was evaluated on neutrophil activation. This compound, in all evaluated concentrations, was able to activate neutrophil superoxide anion release, which could be observed by staining in all cells, while compared to negative and positive controls (Figure 2). This test has been performed qualitatively, by the detection of intracytoplasmic deposits of formazan (bluish granules) in 100\% of neutrophils.

The effect of dotriacontane on neutrophils was supported by performing an additional experiment using a purchased dotriacontane sample (Figure 3). The same effect was observed in both natural and commercial sources of dotriacontane (Table 1).

Table 1 - Activation of neutrophils by isolated dotriacontane (ID) e commercial dotriacontane Sigma-Aldrich ${ }^{\circledR}$ (CD) in qualitative NBT assay

\begin{tabular}{|c|c|c|c|c|}
\hline \multirow{2}{*}{ Sample } & \multicolumn{3}{|c|}{ Controls } & \multirow[b]{2}{*}{$\begin{array}{l}\text { Concentration } \\
\left(10.0 \mu \mathrm{g} \cdot \mathrm{mL}^{-1}\right) \\
\end{array}$} \\
\hline & a NBT & $\mathrm{p}$ NBT & PMA $\left(10.0 \mu \mathrm{g} \cdot \mathrm{mL}^{-1}\right)$ & \\
\hline $\begin{array}{l}\text { Dotriacontane } \\
\text { T. micranthus (ID) }\end{array}$ & AAT & AAT & WA & WA \\
\hline $\begin{array}{l}\text { Dotriacontane } \\
\text { Sigma-Aldrich }{ }^{\circledR}(C D)\end{array}$ & AAT & AAT & WA & WA \\
\hline
\end{tabular}


Figure 2 - Images of neutrophil activation analysis conducted with the substance isolated dotriacontane. (A) Negative control without NBT. (B) Negative control with NBT. (C) Positive control - cells activated with phorbol myristate acetate (PMA). (D) Cells activated with dotriacontane $10.0 \mu \mathrm{g} / \mathrm{mL}$.

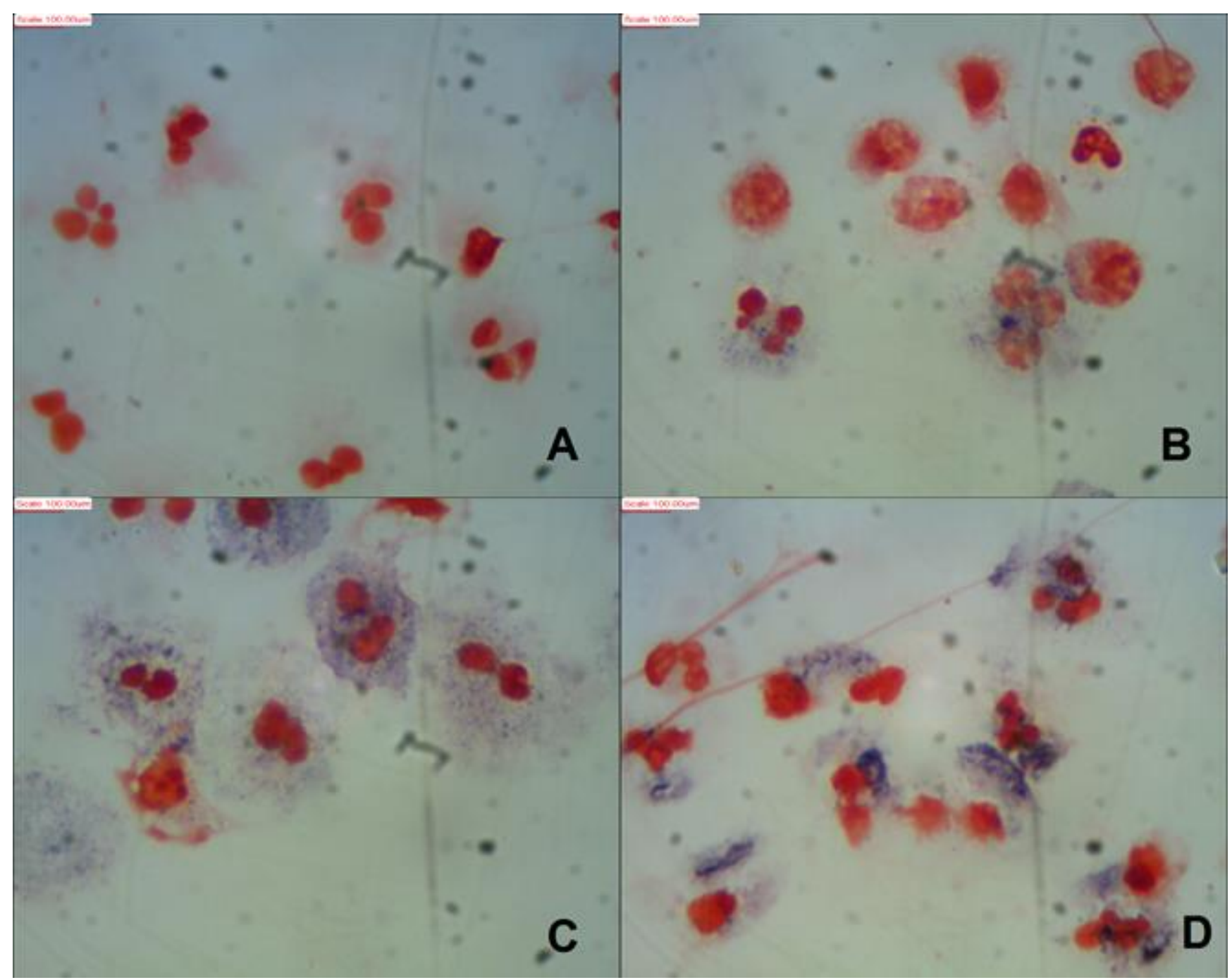


Figure 3 - Images of neutrophil activation analysis conducted with the substance commercial dotriacontane. (A) Negative control without NBT. (B) Negative control with NBT. (C) Positive control - cells activated with phorbol myristate acetate (PMA). (D) Cells activated with dotriacontane $10.0 \mu \mathrm{g} / \mathrm{mL}$.

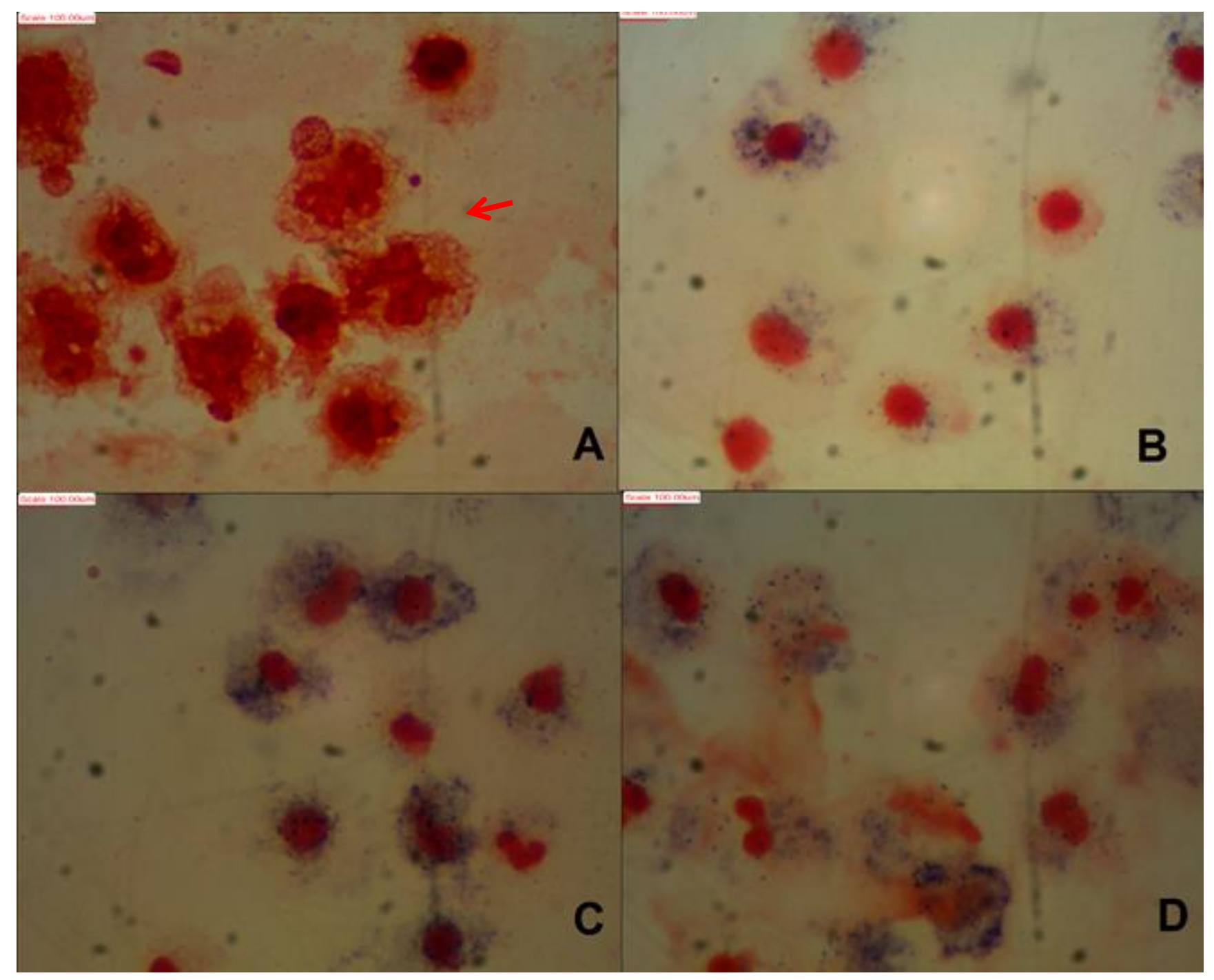

\subsection{Quantitative NBT assay}

The influence of dotriacontane purchased from Sigma-Aldrich ${ }^{\circledR}$ on the activation of human neutrophils was quantitatively evaluated. The results showed significant action when compared to the positive control PMA (Figure 4) confirming the qualitative result. 
Figure 4 - Activation of neutrophils by commercial dotriacontane Sigma-Aldrich ${ }^{\circledR}$ (CD) in quantitative NBT assay

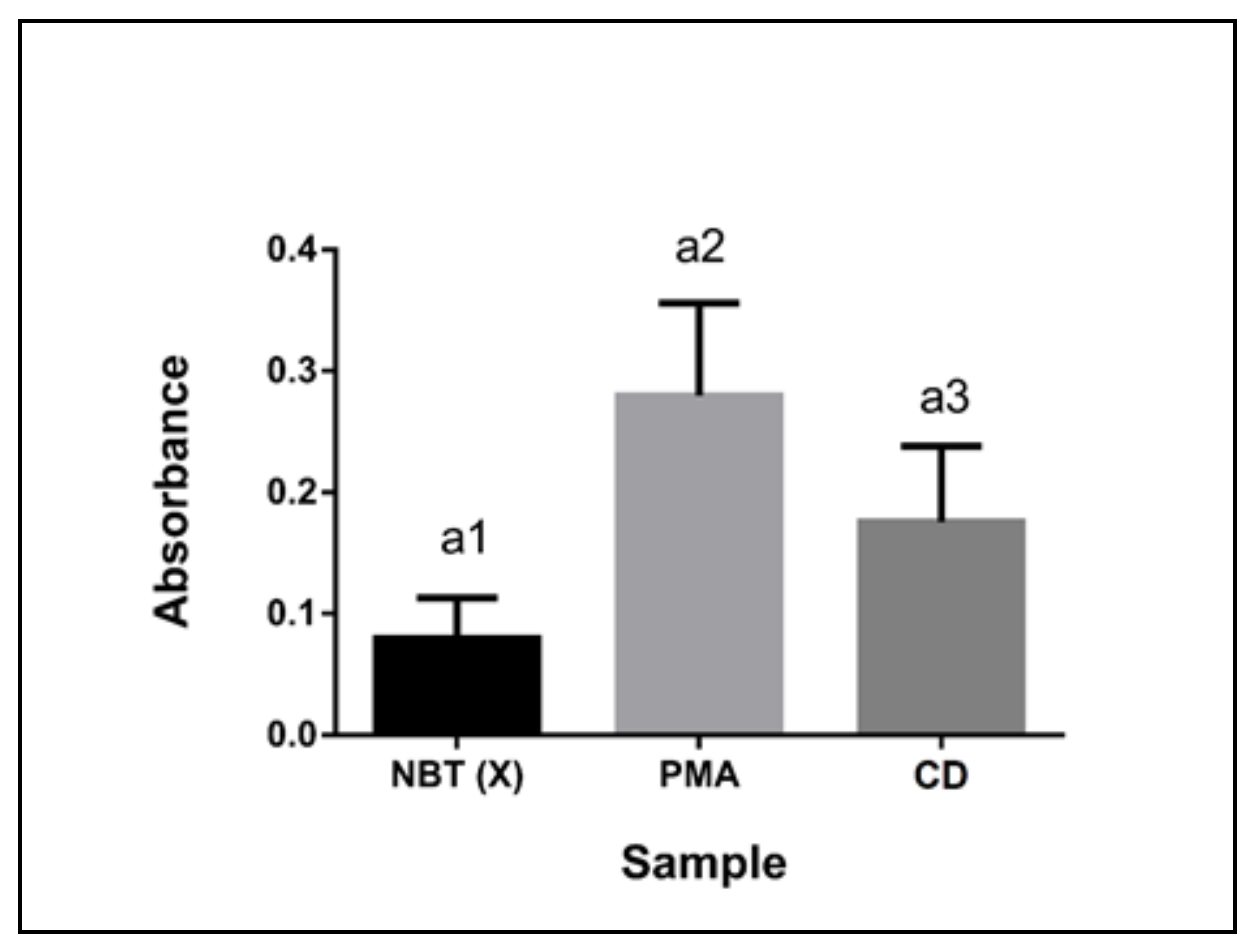

Note: Samples followed by letters with different numbers differ statistically from each other by Tukey's test ( $p<0.05)$.

\section{DISCUSSION}

Alkanes are very common metabolites in plants, mainly in cuticular wax, and are considered as a fingerprint, once each species has a unique characteristic alkane profile (Dove and Mayes, 1991), which is very important from the taxonomic point of view (Gormann et al., 2004). In this way, hydrocarbons are secondary metabolites, described in several botanical families (Tessmann and Dianese, 2002; Kalegari et al., 2011), including Bignoniaceae (Gormann et al., 2004; Roy et al., 2011; Arruda et al., 2012). There are reports about dotriacontane and derivatives from species of the families Piperaceae (Parmar et al., 1998; Nagori et al., 2011), Malpighiaceae (Higuchi et al., 2011), Asteraceae (Lograda et al., 2013), Crassulaceae (Tayade et al., 2013) and Bignoniaceae (Gormann et al., 2004; Roy et al., 2011).

In the species Cinnamomum obtusifolium and Elaeocarpus lanceifolius the dotriacontane obtained excellent inhibition in the concentration of $250 \mu \mathrm{g} / \mathrm{mL}$ against the fungi: Alternaria tenuissima and Alternaria alternata (IC $\mathrm{C}_{50} 43.45 \pm 1.31 \mu \mathrm{g} / \mathrm{mL} / \mathrm{MIC}$ $250 \mu \mathrm{g} / \mathrm{mL} ; \quad I C_{50} 36.63 \pm 0.34 \mu \mathrm{g} / \mathrm{mL} / \mathrm{MIC}: 300 \mu \mathrm{g} / \mathrm{mL}$, respectively). In an assay 
conducted in protein modeling of hydrophobic contacts with transcription regulator of Amt-gene (TF), $\beta$-isopropylmalate dehydrogenase ( $\beta$-ID), endopolygalacturonase (EndoPG) and plasma membrane ATPase, the dotriacontane presented higher affinity for EndoPG, but hydrophobic contacts were also observed for $\beta$-ID, TF and plasma membrane ATPase, the latter two proteins being essential for fungus viability (Bordoloi et al., 2017). However Higuchi et al. (2011) described antitubercular activity against Mycobacterium tuberculosis to dotriacontane. The essential oil of Macleaya cordata (Willd) R., which is one of the components is dotriacontane, presented antimicrobial activity against bacteria B. subtilis ATCC 6633, S. aureus ATCC 27217, S. haemolyticus ATCC 29213, A. tumefaciens ATCC 11158, R. solanacarum GMI1000, E. coli CMCC44102, and against fungi A. niger CMCC (B) 98003 e C. albicans ATCC 10231 (Li and $\mathrm{Yu}, 2014)$. Investigations on Piper betle L. revealed the presence of dotriacontane and its derivatives in the extracts with biological activities, including immunomodulatory activity, although the activity was not associated to dotriacontane (Kanjwan et al., 2008; Nagori et al., 2011).

According to Pearson and Steigbigel (1981) in parasitic infections against the protozoan leishmania neutrophils phagocytose the promastigote form and through oxidative metabolism, enzymatic activity and production of nitric oxide are able to destroy the protozoan. In addition, infected neutrophils secrete chemokines (IL-8 and MIP-1 $\beta$ ) to attract more neutrophils and macrophages to the site of infection (Scapini et al., 2000).

Phorbol esters are produced by plant species of the Euphorbiaceae family, mainly by Croton tiglium L. PMA has the ability to activate protein kinase C (PKC) over a long period of time when it crosses the cell's cytoplasmic membrane (Santos and Araújo, 2000). For Lundqvist-Gustafsson and Bengtsson (1999) human neutrophils stimulated with PMA indicate that NADPH-oxidase is activated. Besides the amount of $\mathrm{H}_{2} \mathrm{O}_{2}$ released from PMA-stimulated cells indicating that the intracellular pool as the plasma membrane group of the oxidase were activated. In addition, when PMA activates PKC, it also phosphorylates and activates various proteins. 
The increase in the percentage of neutrophils positive in the NBT treated group indicates higher phagocytic and bactericidal activity of the neutrophils (Park and Good, 1970). In a review, Jafar et al. (2016) showed that the neutrophilic function in Diabetes mellitus is altered mainly with the decompensated glucose levels, in addition the production of superoxide from activated neutrophils was reduced by the inhibition of G6PD and with the level of this enzyme less than 5\% in neutrophils, in relation to the normal state, the bactericidal activity of phagocytes was blocked. Neutrophil degranulation was reduced by dosing with the enzymes eleastase and MPO, and hyperglycemia interfered with chemotactic migration, decreasing its phagocytic and bactericidal activity, suggesting a decrease in the microbicidal capacity of neutrophils in addition to high levels of glucose to decrease formation of extracellular trap. The reduced neutrophil activity is directly related to the levels of hyperglycemia and lower capacity for phagocytosis (Rocha et al., 2002). Hyperglycemia deregulates neutrophil activation and, impairs the ability of neutrophils in vitro to phagocytose and kill Staphylococcus aureus, Burkholderia pseudomallei and Escherichia coli and to control in vivo S. aureus infections (Javid et al., 2016).

After the tissue injury, the neutrophils are the first line of defense to migrate to the site of injury and can be detected at the site of the injury for approximately 12 hours and are aids in wound healing by producing TNF-a, which stimulates reepitalization (Agaiby and Dyson, 1999). Furthermore, they promote angiogenesis and stimulate the proliferation of keratinocytes and fibroblasts at high levels according to the number of neutrophils recruited. Several genes are transcribed for protein coding in the activation of more neutrophils and other inflammatory cells. Thus, several genes are important for the healing of wounds because they make the neutrophils leaving the bloodstream and reaching the lesion site (Wilgus et al., 2013).

Thus, the results show that dotriacontane activates the neutrophils to release superoxide anions, which may suggest new studies to verify its potential on healing and action on inflammatory processes. Therefore, due to complications caused by $D$. mellitus as reduced healing capacity, dotriacontane may decrease healing time by neutrophils activation. 


\section{CONCLUSIONS}

The compound dotriacontane of Tynanthus micranthus Corr. Mello ex Schum. activated the neutrophils releasing superoxide anions, action confirmed by the use of commercial dotriacontane in qualitative and quantitative assay.

Considering the popular use of species of the genus Tynanthus to combat diabetes, and the popular use of $T$. micranthus for healing, the presented results can contribute to the therapy and studies in a short time, therefore, dotriacontane is a substance with consolidated industrial technological development .

It is noteworthy that this is the first report of dotriacontane in the Tynanthus genus and activity of secondary metabolites on neutrophil activation to release superoxide anions.

\section{SUPPLEMENTARY MATERIALS}

${ }^{1} \mathrm{H}-\mathrm{NMR}$ and ${ }^{13} \mathrm{C}$-NMR spectra of dotriacontane isolated from $\mathrm{T}$. micranthus are available as supporting data.

\section{ACKNOWLEDGMENTS}

The authors are grateful to CNPq, Finep, Fundação Araucária and UFPR for the financial support and fellowships. This study was financed in part by the Coordenação de Aperfeiçoamento de Pessoal de Nível Superior - Brasil (CAPES) - Finance Code 001.

\section{REFERENCES}

Abreu, J.S., Marzocchi-Machado, C.M., Urbaczek, A.C., Fonseca, L.M., Urbinati, E.C. Leukocytes respiratory burst and lysozyme level in pacu (Piaractus mesopotamicus Holmberg, 1887). Braz. J. Biol. 2009; (69): 1133-1139.

Agaiby, A.D., Dyson, M. Immuno-inflammatory cell dynamics during cutaneous wound healing. J. Anat. 1999; (195): 531-542.

Akesson, C., Pero, R.W., Ivars, F. C-Med 100, a hot water extract of Uncaria tomentosa, prolongs lymphocyte survival in vivo. Phytomedicine. 2003; (10): 23-33. 
Arruda, A.L.A., Souza, D.G., Vieira, C.J.B., Oliveira, R.F., Pavan, F.R., Fujimura, C.Q.L., Resende, U.M., Castilho, R.O. Análise fitoquímica e atividade antimicobacteriana de extratos metanólicos de Jacaranda cuspidifolia Mart. (Bignoniaceae). Rev. Bras. Plan. Med. 2012; (14): 276-281.

Balla, A.K., Doi, E.M., Lerner, M.R., Bales, W.D., Archer, L.T., Wunder, P.R., Wilson, M.F., Brackett, D.J. Dose-response effect of in vivo administration o endotoxin on polymorphonuclear leukocytes oxidative burst. Shock. 1996; (5): 357-361.

Balla, A.K., Doi, E.M., Wunder, P.R., Ogle, J.D., Debault, L.E. Human polymorphonuclear leukocyte (PMN) priming/activation by acute ethanol intoxication. Drugs of Abuse, Immunity, and AIDS. 1993; (335): 165-168.

Bin-Hafeez, B., Ahmad, I., Haque, R., Raisuddin, S. Protective effect of Cassia occidentalis L. on cyclophosphamide-induced suppression of humoral immunity in mice. J. Ethnopharmacol. 2001; (75): 13-18.

Bordoloi, M., Saikia, S., Bordoloi, P.K., Kolita, B., Dutta, P.P., Bhuyan, P.D., Dutta, S.C., Rao, P.G. Isolation, characterization and antifungal activity of very long chainalkane derivatives from Cinnamomum obtusifolium, Elaeocarpuslanceifolius and Baccaurea sapida. Journal of Molecular Structure. 2017; (1142); 200-210.

Cansian, F.C., Lima, C.P., Zortéa, F.M., Miguel, O.G., Miguel, M.D. Potencial alelopático de Tynanthus micranthus Corr. Mello ex. Schum. (Bignoniaceae) sobre diásporos de Lactuca sativa L. Rev. Ciênc. Farm. Bás. Apl., 2013; (34): 137-140.

Cansian, F.C., Merino, F.J.Z., Amaral, V.L.L., Salvador, R.A., Campos, P.M., Montrucchio, D.P., Miguel, O.G., Miguel, M.D. Aphrodisiac properties of Tynanthus micranthus Corr. \& Mello ex. Schum in male mice. Afr. J. Pharm. Pharmacol. 2014; (8): 1200-1204.

Cansian, F.C., Miguel, M.D., Miguel, O.G., Miyasaki, C.M.S., Lima, C.P., Kalegari, M., Merino, F.J.Z., Souza, A.M., Cogo, L.L. Phytochemical, toxicity and microbiological activity study of Tynanthus micranthus Corr. Mello ex Schum. (Bignoniaceae). Lat. Am. J. Pharm. 2012; (31): 487-491.

Cansian, F.C., Silva, C.B., Lima, C.P., Merino, F.J.Z., Rech, K.S., Otuki, M.F., Campos, P.M., Miguel, O.G., Miguel, M.D. Tynanthus micranthus: An efficient antioxidant and tyrosinase activity inductor. Afr. J. Pharm. Pharmacol. 2014; (8): 651-657.

Carvalho, J.L.S, Cunico, M.M., Dias, J.F.G., Miguel, M.D., Miguel, O.G. Termoestabilidade de processos extrativos de Nasturtium officinale R. Br., Brassicaceae por sistema Soxhlet modificado. Quím Nova. 2009; (32): 1031-1035.

Correa, M.P. Dicionário das plantas úteis do brasil e das exóticas cultivadas. 1.ed. Rio de Janeiro: IBDF, 1974. 687 p.

Corrêa, M.F.P., Melo, G.O., Costa, S.S. Substâncias de origem vegetal potencialmente úteis na terapia da asma. Rev. Brasil. de Farmacog. 2008; (18): 785-797. 
Costa-Silva, T.A., Grecco, S.S., Sousa, F.S., Lago, J.H., Martins, E.G., Terrazas, C.A., Varikuti, S., Owens, K.L., Beverley, S.M., Satoskar, A.R., Tempone, A.G. Immunomodulatory and antileishmanial activity of phenylpropanoid dimers isolated from Nectandra leucantha. J. Nat. 2015; (78): 653-657.

Cruvinel, W.M., Júnior, D.M., Araújo, J.A.P., Catelan, T.T.T., Souza, A.W.S., Silva, N.P., Andrade, L.E.C. Sistema Imunitário - Parte I: Fundamentos da imunidade inata com ênfase nos mecanismos moleculares e celulares da resposta inflamatória. Rev. Bras. Reumatol. 2010; (50): 434-461.

Custódio, D.L., Burgo, R.P., Moriel, B., Barbosa, A.M., Rezende, M.I., Daniel, J.F.S., Pinto, J.P., Bianchini, E., Faria, T.J. Antimicrobial activity of essential oils from Pimenta pseudocaryophyllus and Tynanthus micranthus. Braz. Arch. Biol. Technol. 2010; (53): 1363-1369.

Davis, L., Kuttan, G. Immunomodulatory activity of Withania somnifera. J. Ethnopharmacol. 2000; (71): 193-202.

Dove, H., Mayes, R.W. The use of plant wax alkanes as marker substances in studies of the nutrition of herbivores: a review. Aust. J. Agric. Res. 1991; (42): 913-952.

Dulbecco, R., Vogt, M. Plaque formation and isolation of pure lines with poliomyelitis viruses. The Journal of Experimental Medicine. 1954; (99): 167-182.

Ferreira, D.F. Sisvar: a computer statistical analysis system. Ciência e Agrotecnologia. 2011; (35): 1039-1042.

Ferrier, J. Ethnobotany, pharmacology, and metabolomics of antidiabetic plants used by the Eeyou Istchee Cree, Lukomir Highlanders, and Q'eqchi' Maya. Canada. [Dissertation of master degree. Faculty of Graduate and Postdoctoral Studies. University of Ottawa]. 2014. 193 p.

Ghule, B.V., Murugananthan G., Nakhat, P.D., Yeole, P.G. Immunostimulant effects of Capparis zeylanica Linn. leaves. J. Ethnopharmacol. 2006; (108): 311-315.

Ghule, B.V., Yeole, P.G. In vitro and in vivo immunomodulatory activities of iridoids fraction from Barleria prionitis Linn. J. Ethnopharmacol. 2012; (141): 424-431.

Glasser, L., Fiederlein, R.I. The effect of various cell separation procedures on assays of neutrophil function. American Journal of Clinical Pathology. 1990; (93): 662-669.

Gormann, R., Schreiber, L., Kolodziej, H. Cuticular wax profiles of leaves of some traditionally used african Bignoniaceae. Z. Naturforsch. 2004; (59): 9-10.

Higuchi, C.T., Sannomiya, M., Pavan, F.R., Leite, S.R.A., Sato, D.N., Franzblau, S.G., Sacramento, L.V.S., Vilegas, W., Leite, C.Q.F., 2011. Byrsonima fagifolia Niedenzu apolar compounds with antitubercular activity. J. Evid. Based Complementary Altern. Med. $2011 ; 1-5$. 
Jafar, N., Edriss, H., Nugent, K. The effect of short-term hyperglycemia on the innate immune system. Am. J. Med. Sci. 2016; (351), 201-211.

Javid, A., Zlotnikov, N., Pětrošová, H., Tang, T.T., Zhang, Y., Bansal, A.K., Ebady, R., Parikh, M., Ahmed, M., Sun, C., Newbigging, S., Kim, Y.R., Sosa, M.S., Glogauer, M., Moriarty, T.J.,. Hyperglycemia impairs neutrophil-mediated bacterial clearance in mice infected with the Lyme disease pathogen. PLOS ONE. 2016; 1-20.

Johansson, S., Göransson, U., Luijendijk, T., Backlund, A., Claeson, P., Bohlin, L. A neutrophil multitarget functional bioassay to detect anti-inflammatory Natural Products. J. Nat. Prod. 2002; (65), 32-41

Kalegari, M., Miguel, M.D., Dias, J.F.G., Lordello, A.L.L., Lima, C.P., Miyazaki, C.M.S., Warumby, S.M.Z., Verdam, M.C.S., Miguel, O.G. Phytochemical constituents and preliminary toxicity evaluation of leaves from Rourea induta Planch. (Connaraceae). Braz. J. Pharm. Sci. 2011; (47), 635-642.

Kang, S., Min, H. Ginseng, the "Immunity Boost": The Effects of Panax ginseng on Immune System. J. Ginseng Res. 2012; (36), 354-368.

Kanjwani, D.G., Marathe, T.P., Chiplunkar, S.V., Sathaye, S.S. Evaluation of immunomodulatory activity of methanolic extract of Piper betel. J. Immunol. 2008; (67), 589-593.

Levinsky, R.J., Harvey, B.A.M., Rodeck, C.H., Soothill, J.F. Phorbol myristate acetate stimulated NBT test: a simple method suitable for antenatal diagnosis of chronic granulomatous disease. Clinical \& Experimental Immunology. 1983; (54), 595-598.

$\mathrm{Li}, \mathrm{C} ., \mathrm{Yu}, \mathrm{J}$. Chemical Composition and Antimicrobial Activity of Essential Oils of Stems of Macleaya cordata (Willd) R. Br. Asian Journal of Chemistry. 2014; (26), 7741-7745.

Lograda, T., Ramdani, M., Chalard, P., Figuered, G., Khalfoune, K., Silini, H. Phytochemistry, antibacterial activity and chromosome number of Centaurea solstitialis L. grown in Algeria. Global J. Res. Med. Plants and Indigen. Med. 2013; (2), 675-684.

Lopes, M. M. M., Carvalho-Okano, R.M., Souza, A.L., Paiva, H.N. Crescimento de mudas de Cipó-Cravo (Tynanthus fasciculatus Miers), uma Liana com potencial medicinal. Revista Árvore. 2008; (32), 211-216.

Lundqvist-Gustafsson, H., Bengtsson, T. Activation of the granule pool of the NADPH oxidase accelerates apoptosis in human neutrophils. Journal of Leukocyte Biology. 1999; (65), 196-204.

Markert, M., Andrews, P.C., Babior, B.M. Measurement of $\mathrm{O}_{2}^{-}$production by human neutrophils. The preparation and assay of NADPH oxidase-containing particles from human neutrophils. Methods in Enzymology. 1984; (105), 358-365. 
Muñoz, V., Sauvain, M., Bourdy, G., Callapa, J., Rojas, I., Vargas, L., Tae, A., Deharo, E. The search for natural bioactive compounds through a multidisciplinary approach in Bolivia. Part II. Antimalarial activity of some plants used by Mosetene Indians. J. Ethnopharm. 2000; (69), 139-155.

Nagori, K., Singh, M.K., Alexander, A., Kumar, T., Dewangan, D., Badwaik, H., Tripathi, D.K. Piper betle L.: A review on its ethnobotany, phytochemistry, pharmacological profile and profiling by new hyphenated technique DART-MS (Direct Analysis in Real Time Mass Spectrometry). J.Pharm. Res. 2011; (4), 2991-2997.

Park, B.H., Fikrig, S.M., Smithwick, E.M. Infection and nitroblue-tetrazolium reduction by neutrophils. A diagnostiv acid. Lancet. 1968; (7), 532-534.

Park, H.H., Good, R.A. N.B.T. test stimulated. Lancet. 1970; (19), 616.

Parmar, V.S., Jain, S.C., Gupta, S., Talwar, S., Rajwanshi, V.K., Kumar, R., Azim, A., Malhotra, S., Kumar, N., Jains, R., Sharma, N.K., Tyagi, O.D., Lawrie, S.J., Errington, W., Howarth, O.W., Olsen, C.E., Singh, S.K., Wengel, J. Polyphenols and alkaloids from Piper species. Phytochem. 1998; (49), 1069-1078.

Pearson, R.D., Steigbigel, R.T. Phagocytosis and killing of the protozoan Leishmania donovani by human polymorphonuclear leukocytes. Journal of Immunology. 1981; (127), 1438-1443.

Plaza, A., Montoro, P., Benavides, A., Pizza, C., Piacente, S. Phenylpropanoid Glycosides from Tynanthus panurensis: Characterization and LC-MS Quantitative Analysis. J. Agric. Food Chem. 2005; ( 53), 2853-2858.

Rocha, J.L.L., Baggio, H.C.C., Cunha C.A., Niclewicz, E.A., Leite, S.A.O., Baptista, M.I.D.K. Aspectos relevantes da interface entre Diabetes mellitus e infecção. Arq. Bras. Endocrinol. Metab. 2002; (46), 221-229.

Roy, P., Amdekar, S., Kumar, A., Singh, V. Preliminary study of the antioxidant properties of flowers and roots of Pyrostegia venusta (Ker Gawl) Miers. BMC Complement Altern Med. 2011; (11), 69.

Santos, A.A., Araújo, E.G. The effect of PKC activation on the survival of rat retinal ganglion cells in culture. Brain Research. 2000; (853), 338-343.

Scapini, P., Lapinet-Vera, J.A., Gasperini, S., Calzetti, F., Bazzoni, F., Cassatella, M.A. The neutrophil as a cellular source of chemokines. Immunology Review. 2000; (177), 195203.

Sharma, M.L., Singh, B., Chandan, B.K., Khajuria, A., Kaul, A., Bani, S., Banerjeee, S.K., Gambhir, S.S. Actions of some flavonoids on specific and non-specific immune mechanisms. Phytomedicine. 1996; (3), 191-195. 
Sharma, U., Bala, M., Kumar, N., Singh, B., Munshi, R., Bhalerao, S. Immunomodulatory active compounds from Tinospora cordifolia. Journal of Ethnopharmacology. 2012; (141), 918-926.

Tayade, A.B., Dhar, P., Kumar, J., Sharma, M., Chauhan, R.S., Chaurasia, O.P., Srivastava, R.B. Chemometric Profile of Root Extracts of Rhodiola imbricata Edgew. with Hyphenated Gas Chromatography Mass Spectrometric Technique. PloS One. 2013; (8), e52797.

Tessmann, D., Dianese, J.C. Hentriacontane: a leaf hydrocarbon from Syzygium jambos with stimulatory effects on the germination of urediniospores of Puccinia psidii. Fitopatol. Bras. 2002; (27), 538-542.

Verhoef, Jan. Phagocytosis. In: Roitt, I. M., Delves, P. J. (Ed) Encyclopedia of Immunology. Academic Press Limited. 1992; 1220-1222.

Wunder, P.R., Waner, J.L., Balla, A.K. Alcohol, neutrophils, and viral infections. In: Advances in the Biosciences. Pergamon Press Ltd. 1993; (86), 449-455.

Zychlinsky, A., Weinrauch, Y., Weiss, J. Forum in immunology. Introduction: forum in immunology on neutrophils. Microbes and Infection. 2003; (5), 1289-1291. 